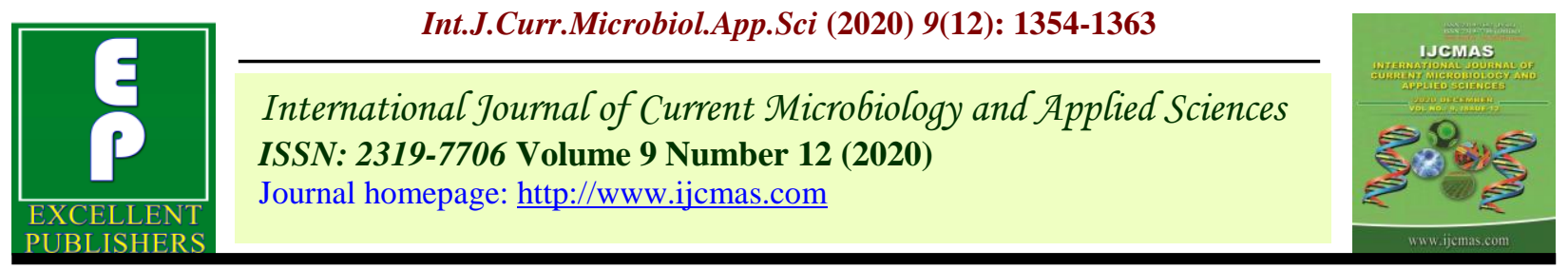

Review Article

https://doi.org/10.20546/ijcmas.2020.912.165

\title{
Field Study on the Beneficial Effects of Fresh Herbals against Warts in Cattle: A Review of Clinical Cases
}

\author{
N. Karthick Kumar ${ }^{1 *}$, S. Sivaraman ${ }^{2}$ and N. Punniamurthy ${ }^{3}$ \\ ${ }^{1}$ Veterinary Assistant Surgeon, Veterinary Dispensary, Kottagudi, Melur (Tk), India \\ ${ }^{2}$ Veterinary Clinical Complex, Veterinary College and Research Institute, Salem, India \\ ${ }^{3}$ Ethnoveterinary $R \& D$ Centre, TANUVAS, Thanjavu, India \\ *Corresponding author
}

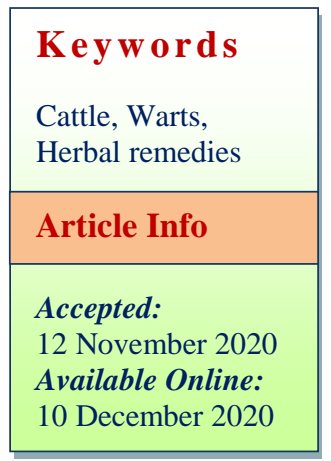

\section{A B S T R A C T}

A study was conducted to evaluate the clinical effectiveness of a herbal preparation, in crossbreed cattle, affected by warts. The incidence of warts $(n=13)$ was higher in females $(92.3 \%)$ than males $(7.69 \%)$ and younger animals were affected more $(61.5 \%)$. The wartlesions were found to be more in the teats $(30.7 \%)$ and neck $(23.07 \%)$. The time needed for the healing of warts was recorded individually in all the cattle under study, of which six cattle $(46.1 \%)$ were observed for 4 months. The herbal paste was made freshly of Euphorbia hirta latex and leaves, Allium sativum bulbs, Musa paradisiaca peel, Acalypha indica leaves and Zingiber officinale rhizomes. All the animals were treated externally twice a day till the warts got completely cleared. Monitored once in ten days for signs of recovery for 60 days. By the end of second week, warts showed signs of healing to the herbal treatment. The overall success rate was achieved in $11(84.6 \%)$ cattle with a mean recovery period of 28.3 days. This real-time field study, has proved that this herbal remedy was useful in the treatment of warts in cattle, in a stand-alone mode obviating the use of any synthetic chemical(s) and also found to be very economical for the farmer(s).

\section{Introduction}

Warts and Papillomatos is benign in nature and are characterized by small to medium sized growths on skin or mucous membranes. Bovine Papilloma virus (BPV) is a group of DNA viruses of the family Papillomaviridae that causes papilloma and warts in cattle. Thirteen types of bovine papilloma viruses have been identified in cattle (Devilliers et al., 2004). Cattle types show site-specificity (Table 1). BPV 1 and BPV 2 comprise the major cutaneous fibropapilloma (Catroxo et al., 2013). Warts develop after the introduction of an infective virus through the cuts, abrasions; micro trauma of the skin, BPV induces the formation of papilloma or warts by targeting the keratinocytes. Infection of epithelial cells results in hyperplasia with subsequent degeneration and hyperkeratinisation. These benign changes occur usually 4 to 6 weeks after exposure (Campo, 2002). Warts occur due to several factors including inheritance, hormonal disorders and suppressed immune system (Campo et al., 1997). The immunity of animals plays a major role in acquiring the infection (Inayat et al., 1999). The cattle 
carrying the virus as reservoir and source of the infection, intermediate sources of infection could be contaminated fences, feeders, ropes etc. (Nasir and Campo, 2008).

Warts have been widely found to affect cattle worldwide. In India Bovine cutaneous warts identified as BPV type 1 and type 2 was reported (Singh et al., 2009). BPV type 10 warts in the teat were recorded by Rai et al., (2011). Campo (2006) reported several economic consequences, in a cow with teat papillomas that cannot be milked and young calves cannot suckle, and often the pedunculated papillomas snap off, the sites become infected and mastitis may ensue with distortion of the milk canals.

A wart is an important disease leading to economic depreciation of animals and leads to deterioration of the quality of leather. The wart may progress to cancer due to the synergistic action of genetic or environmental co-factors (Leal et al., 2003).

Somvanshi and Sharma (1986) have stated that there is no effective allopathic veterinary medicine available for wart(s) management.

According to the World Health Organization (WHO) about $80 \%$ of world population depends on traditional medicines, especially herbal medicines for their Primary Health Care needs. Ethno veterinary medicine (EVM) is a branch of science which deals with the study of traditional knowledge, methods, skills and practices used for treating various ailments of livestock (Corkle, 1986). Ethno veterinary medicinal practices are often cheap, safe, and based on local available resources and strengths. EVM can provide useful alternatives to conventional animal health care (Kumar, 2002). In developing countries, low-income category such as farmers, in remote and isolated village(s) use folk medicine for the treatment of common infections. The study was aimed to evaluate the herbal remedies used in the field in cattle suffering from warts.

\section{Materials and Methods}

Study area: The study was conducted in thirteen crossbreed cattle affected with warts presented at the Veterinary dispensary, Kottagudi, Melur (Tk), Madurai (Dist), Tamil Nadu India (2017 to 2019).

Animals: Thirteen crossbreed cattle affected with warts in different seasons and times,. The age of animals ranged from 10 months to 6.5 years, the duration of warts occurred from one month to six months.

Clinical examination: Body temperature and the appetite of the animals were normal. Body condition of heavily affected cattle was generally poor (Constable, P. D et al., 2017). The site, size and diameter of warts were recorded as shown in the table 2 .

\section{Ingredients}

$\begin{array}{ll}\begin{array}{l}\text { Euphorbia hirta } \\ \text { fresh leaves with latex }\end{array} & \text { One handful of } \\ \begin{array}{l}\text { Allium sativum (Garlic)- } \\ \text { Musa paradisiaca }-\end{array} & \begin{array}{l}3 \text { bulbs } \\ \text { 2 peels }\end{array} \\ \begin{array}{l}\text { Acalypha indica } \\ \text { fresh leaves }\end{array} & \text { One handful of } \\ \begin{array}{l}\text { Zingiber officinale (ginger) } \\ \text { grams of fresh rhizome }\end{array} & -\end{array}$

The above ingredients were enough for a $10 \mathrm{~cm}$ diameter size warts, the herbal remedies paste was prepared, depending on the size of warts.

\section{Preparation}

Garlic and ginger were crushed into a fine paste, after that the inner side of the banana peel was scraped by the blunt side of the knife, and this banana peel paste was taken, then added Euphorbia hirta and Acalypha 
indica leaves and mixed together to a fine paste.

\section{Application}

The latex from the Euphorbia hirta plant was applied to the root of the warts. Subsequently, the prepared herbal remedies paste was applied over the affected part of the animal body twice in a day till the warts were completely disappeared. All the animals were monitored once in ten days for signs of recovery for up to 60 days. No other therapy was given during the treatment.

\section{Results and Discussion}

Warts have recently grown in importance due to its association with cancer and immune suppression conditions (Campo, 2002). Animals can also develop warts extensively in the upper gastrointestinal tract and consequently, present difficulty to feed and breathe, resulting in a debilitated animal that may cause death (Campo, 2002).

In the present study, the incidence rate of warts was significantly higher in females 12 $(92.3 \%)$ than in males $1(7.69 \%)$. Previously (Mohammed et al., 2017) reported similar findings that the incidence was higher in females $(79.14 \%)$ than males $(20.85 \%)$. Infection may occur high in female cattle, usually under stress factors, such as gestation, lactation and progression of age. On another hand, male cattle are usually directed to fattening and meat production and are mostly slaughtered at the age of two years or less (Fayez Awadalla Salib et al., 2008).

In the current study out of 13 animals, two animals were less than 1 year of age, six animals were 2 to 3 years of age, and two animals were 4 to 5 years of age and three animals were over 5 years of age. It appears that the younger age-group are more susceptible than the adult as described by Otter and Leonard (2003). They recorded warts at young ages; it is due to illdevelopment immune system, alkaline $\mathrm{Ph}$ of the skin of young ages, most of the time these animals have been weaned early with less maternal derived antibodies that may facilitate the virus infection.

In the current study warts were found in different parts of the body. The number of cases and percentage of warts lesions regarding the site was recorded as follows: face $2(15.3 \%)$, eye $2(15.3 \%)$, leg $1(7.6 \%)$, teat $4(30.7 \%)$, udder $1(7.6 \%)$ and neck 3 (23.07\%). The most commonly affected sites were teat and neck. Devilliers et al., (2004) have reported similar results. Mc Murray et al., (2001) indicated that warts differ in their tissue specificity depending on the genotype of the virus and associated disease.

Size of warts, less than one centimeter diameter warts got completely disappeared at the end of $2^{\text {nd }}$ week of treatment. Warts with two-centimeters to ten- centimeters diameter warts got completely disappeared by the end of the $6^{\text {th }}$ week.. Warts above ten-centimeter diameter took $7^{\text {to }} 8$ weeks to disappear. Two animals showed no improvement beyond 60 days. The time taken for warts to disappear may be varying on the virus type, location, and size of warts. On the other hand, may be farmers not implementing these herbal remedies properly.

Ethno veterinary practices are generally cheap, safe and based on local resources and strengths. These can provide useful alternative to conventional animal health care (Kumar, 2002).

Basker joshi (2011) reported that local tribes and vangujjars of Kashipur (Uttarakhand) used Euphorbia hirta milky latex in the treatment of warts. Euphorbia hirta plant is used for its anti-bacterial, anti-malarial, antiinflammatory, anti-fungal anti-oxidant property (Kumar et al., 2010) (Fig. 1-4). 
Table.1 Types of bovine papilloma virus

\begin{tabular}{|c|c|l|c|}
\hline SL.NO & TYPES & \multicolumn{1}{|c|}{ LESIONS } & REPORTED BY \\
\hline $\mathbf{1}$ & $\begin{array}{c}\text { BPV 1, BPV2 and } \\
\text { BPV 13 }\end{array}$ & $\begin{array}{l}\text { Fibropapillomas are } \\
\text { associated with sub } \\
\text { epithelial fibroblasts }\end{array}$ & $\begin{array}{c}\text { Jelinek and Tachezy } \\
(2005)\end{array}$ \\
\hline $\mathbf{2}$ & $\begin{array}{c}\text { BPV } \\
\text { 3,4,6,9,10,11,12. }\end{array}$ & $\begin{array}{l}\text { Epitheliotropic, inducing } \\
\text { the formation of true } \\
\text { papilloma without the } \\
\text { involvement of fibroblasts }\end{array}$ & Jarrett et al., 1984 \\
\hline $\mathbf{3}$ & BPV 5 and 8 & $\begin{array}{l}\text { Potential to induce both } \\
\text { fibropapillomas and true } \\
\text { papilloma }\end{array}$ & Bloch et al., 1994 \\
\hline $\mathbf{4}$ & BPV 7 & Cutaneous papilloma & Ogawa et al., 2007 \\
\hline
\end{tabular}

Table.3 Scientific classifications

1.Euphorbia hirta KINGDOM

FAMILY

GENUS

SPECIES

BINOMIAL NAME

TAMIL NAME

\section{Allium sativum}

\section{KINGDOM}

FAMILY

GENUS

SPECIES

BINOMIAL NAME

TAMIL NAME

3. Musa paradisiaca KINGDOM ORDER

FAMILY

GENUS

SPECIES

BINOMIAL NAME

TAMIL NAME

4.Acalypha indica

KINGDOM

FAMILY

GENUS

SPECIES

BINOMIAL NAME

TAMIL NAME

5.Zingiber officinale

KINGDOM

FAMILY

GENUS

SPECIES

BINOMIAL NAME

TAMIL NAME
Plantae

Euporbiaceae

Euporbia

hirta

Euphorbia hirta

Amman pacharisi

Plantae

Amaryllidaceae

Allium

sativum

Allium sativum

Vellaipoondu
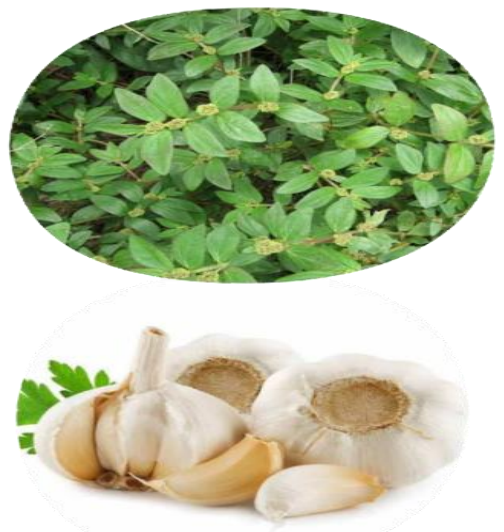

Plantae

Zingiberales

Musaceae

Musa

paradisiaca

Musa paradisiaca

Vaalaipalam

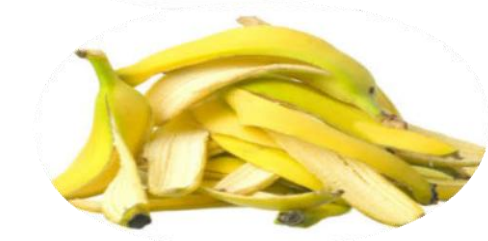

Plantae

Euporbiaceae

Acalypha

indica

Acalypha indica

Kuppaimeni

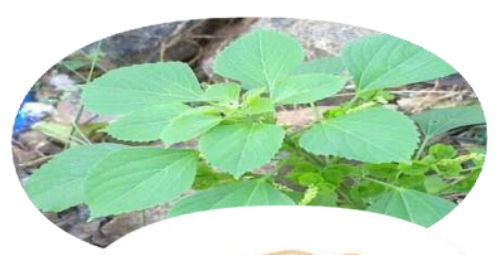

Plantae

Zingiberaceae

Zingiber

officinale

officinale
Zingiber officinale

Inji

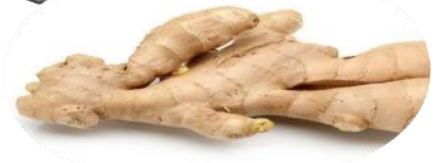


Table.2 Baseline characteristics of affected animals

\begin{tabular}{|c|c|c|c|c|c|c|}
\hline $\begin{array}{c}\text { Case } \\
\text { no }\end{array}$ & $\begin{array}{c}\text { Age } \\
\text { (In } \\
\text { months) }\end{array}$ & $\begin{array}{c}\text { Site } \\
\text { of } \\
\text { warts }\end{array}$ & Warts appearance & $\begin{array}{c}\text { Diamet } \\
\text { er of } \\
\text { warts }\end{array}$ & $\begin{array}{c}\text { Duration } \\
\text { of warts } \\
\text { (In } \\
\text { months) }\end{array}$ & Response to treatment \\
\hline $\mathbf{1}$ & 10 & Face & Pea-nut appearance & $<1 \mathrm{~cm}$ & 2 & $\begin{array}{l}\text { Regression started after } 1 \text { st } \\
\text { week and wart disappeared at } \\
\text { the end of } 2 \text { nd week ( } 12 \text { days) }\end{array}$ \\
\hline 2 & 24 & Eye & $\begin{array}{l}\text { Finger-like projection } \\
\text { appearance } \\
\text { (Multiple warts) }\end{array}$ & $\begin{array}{l}3 \mathrm{~cm}- \\
5 \mathrm{~cm}\end{array}$ & 3 to 4 & $\begin{array}{l}\text { Regression started after } 2 \mathrm{nd} \\
\text { week and wart disappeared at } \\
\text { the end of } 5 \text { th week ( } 33 \text { days) }\end{array}$ \\
\hline 3 & 36 & Leg & $\begin{array}{l}\text { Finger-like projection } \\
\text { appearance }\end{array}$ & $3 \mathrm{~cm}$ & 2 & Not-recovered \\
\hline 4 & 10 & Face & Pea-nut appearance & $2 \mathrm{~cm}$ & 2 & $\begin{array}{l}\text { Regression start after } 1 \text { st week } \\
\text { and wart disappeared at the end } \\
\text { of } 2 \text { nd week ( } 15 \text { days) }\end{array}$ \\
\hline 5 & 60 & Teat & $\begin{array}{l}\text { Pea-nut appearance } \\
\text { (Multiple warts) }\end{array}$ & $\begin{array}{l}1 \mathrm{~cm} \mathrm{-} \\
2 \mathrm{~cm}\end{array}$ & 3 to 4 & $\begin{array}{l}\text { Regression start after } 2 \text { nd week } \\
\text { and wart disappeared at the end } \\
\text { of } 5 \text { th week ( } 31 \text { days) }\end{array}$ \\
\hline 6 & 72 & Teat & $\begin{array}{l}\text { Granule-like } \\
\text { appearance } \\
\text { (Multiple warts) }\end{array}$ & $\begin{array}{l}1 \mathrm{~cm}- \\
2 \mathrm{~cm}\end{array}$ & 3 to 4 & $\begin{array}{l}\text { Regression start after } 2 \text { nd week } \\
\text { and wart disappeared at the end } \\
\text { of } 5 \text { th week ( } 35 \text { days) }\end{array}$ \\
\hline 7 & 78 & Udder & $\begin{array}{l}\text { Pea-nut appearance } \\
\text { (Multiple warts) }\end{array}$ & $\begin{array}{l}1 \mathrm{~cm}- \\
2 \mathrm{~cm}\end{array}$ & 5 to 6 & $\begin{array}{l}\text { Regression start after } 2 \text { nd week } \\
\text { and wart disappear noticed } \\
\text { after the } 6 \text { th week ( } 39 \text { days) }\end{array}$ \\
\hline 8 & 30 & Neck & $\begin{array}{c}\text { Cluster warts } \\
\text { (Bunch of grapes) }\end{array}$ & $>10 \mathrm{~cm}$ & 5 to 6 & $\begin{array}{l}\text { Regression start after } 4 \text { th week } \\
\text { and wart disappear at the end } \\
\text { of } 7 \text { th week ( } 49 \text { days) }\end{array}$ \\
\hline 9 & 24 & Neck & $\begin{array}{c}\text { Cluster warts } \\
\text { (Bunch of grapes) }\end{array}$ & $>10 \mathrm{~cm}$ & 5 to 6 & $\begin{array}{l}\text { Regression start after } 4 \text { th week } \\
\text { and wart disappear noticed } \\
\text { after the } 8 \text { th week ( } 52 \text { days) }\end{array}$ \\
\hline 10 & 30 & Eye & $\begin{array}{l}\text { Finger-like projection } \\
\text { appearance }\end{array}$ & $5 \mathrm{~cm}$ & 5 to 6 & $\begin{array}{l}\text { Regression start after } 2 \text { nd week } \\
\text { and wart disappeared at the end } \\
\text { of } 5 \text { th week ( } 32 \text { days) }\end{array}$ \\
\hline 11 & 36 & Neck & $\begin{array}{l}\text { Lemon like } \\
\text { appearance }\end{array}$ & $6 \mathrm{~cm}$ & 3 to 4 & Not-recovered \\
\hline 12 & 72 & Teat & $\begin{array}{l}\text { Pea-nut appearance } \\
\text { (Multiple warts) }\end{array}$ & $\begin{array}{l}1 \mathrm{~cm} \mathrm{-} \\
2 \mathrm{~cm}\end{array}$ & 3 to 4 & $\begin{array}{l}\text { Regression start after } 2 \text { nd week } \\
\text { and wart disappear noticed } \\
\text { after the 6th week ( } 38 \text { days) }\end{array}$ \\
\hline 13 & 48 & Teat & $\begin{array}{l}\text { Pea-nut appearance } \\
\text { (Multiple warts) }\end{array}$ & $\begin{array}{l}1 \mathrm{~cm} \mathrm{-} \\
2 \mathrm{~cm}\end{array}$ & 3 to 4 & $\begin{array}{l}\text { Regression start after } 2 \text { nd week } \\
\text { and wart disappeared at the end } \\
\text { of } 5 \text { th week ( } 32 \text { days) }\end{array}$ \\
\hline \multicolumn{6}{|c|}{ The overall success rate with mean recovery period } & $11(85.6 \%)$ with 28.3 days \\
\hline
\end{tabular}


Fig.1 (A) Warts around eye before treatment (B) Complete regression of warts after treatment (33 days)

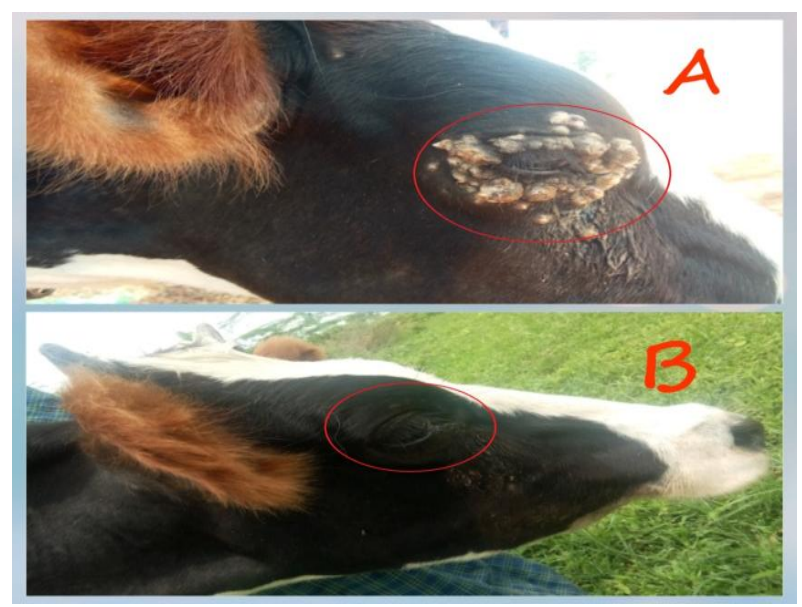

Fig.2 (A) warts in teat of cow - Before treatment. (B) Complete regression of warts- After treatment (35 days)

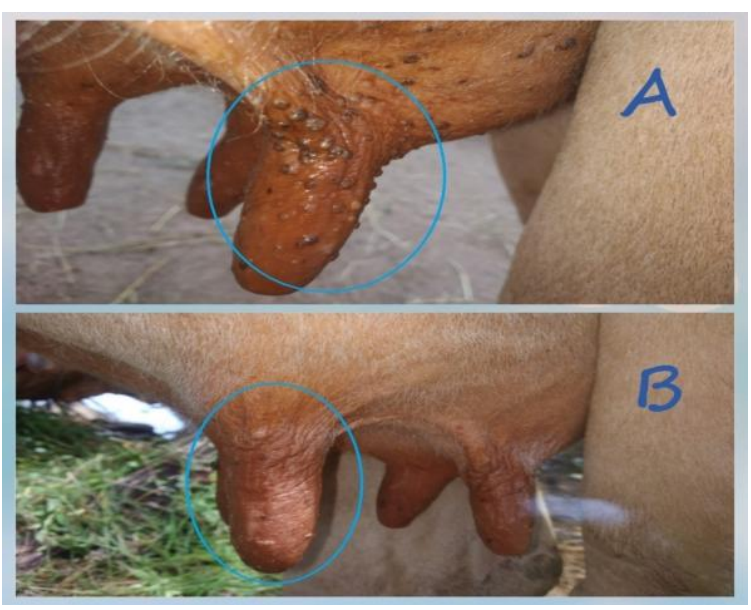

Fig.3 (A) Warts on the neck of animals- Before treatment B) Complete regression of warts-After treatment (49 days)

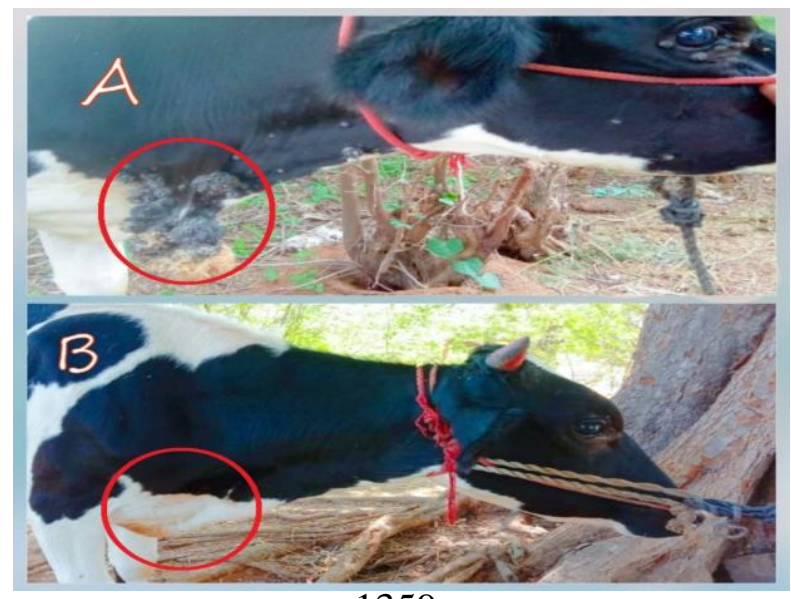


Fig.4 (A) Warts on the neck of animal before treatment (B) Wart complete disappeared after (52 days) treatment

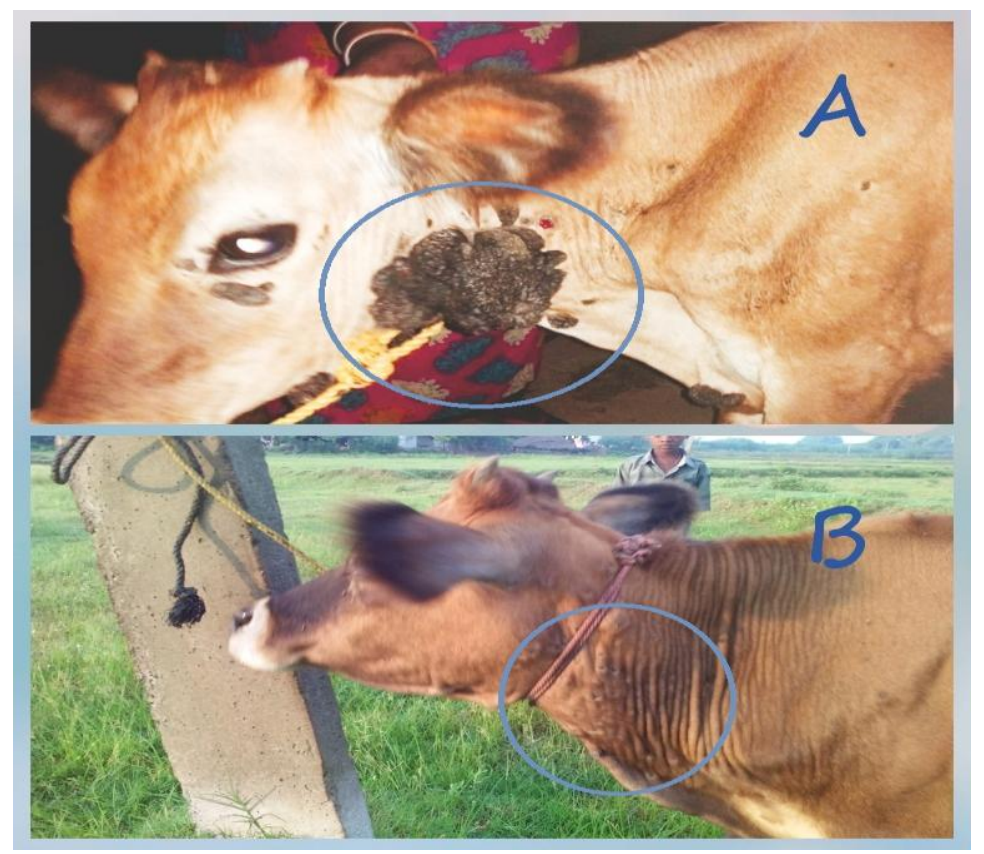

Zabra beygom mosavi et al., (2018) reported $69.7 \%$ of human warts patients showed complete clearing of the lesions by using garlic. In vitro studies on garlic showed that it can enhance Natural Killer (NK) cells, which are an important part of the immune system in fighting cancers, viruses and certain bacteria (Agarwal 1996). Silverberg NB (2002) reported that garlic was effective on the complete resolution of cutaneous warts.

Sampath kumar et al., (2012) reported antifungal, anti-biotic and anti-oxidant activity found in the peel of ripe bananas, and also used to treat the warts and helps to reduce the irritation and inflammation of the skin.

Islam et al., (2015) reported that Acalypha indica contains a phytol compound, and they reported phytol compound has anti-microbial, anti-mutagenic, anti- tumoral, cytotoxic and anti-teratogenic.

Awang (1992) recorded that the ginger revealed anti-inflammatory, anti-oxidant, anti- microbial activities and also utilized to treat warts.

Though there are a lot of remedies available to treat warts such as anthiomaline, autogenous blood, homeopathy remedies etc, with levels of success vary. No published study was found on the usage of herbal remedies to treat warts in the veterinary field. At the moment, our aim was to establish a clinically useful and affordable treatment for curing warts.

In the present study the overall complete clearance was achieved in 11(84.6\%) animals with a mean recovery period of 28.3 days. This report was comparatively higher than the earlier reports of (Kavitha et al., 2014) who achieved a success rate of anthiomaline (81\%), local application of thuja ointment $(58 \%)$, oral treatment of thuja $(70 \%)$ : However this success rate was lower than the other studies of Kavitha et al., (2014) who achieved a $92 \%$ success rate by using autogenous blood. 
However, Terziev et al., (2015) reported that the autogenous vaccine yielded good results but only for small warts up to 1-2 cm diameter, whereas the outcome in larger growth was not satisfactory, as well as Silva et al (2004) reported it was economically viable to repeat the continuous treatment in animals that did not recover after the first therapeutic intervention. In this situation, these herbal remedies can be used to treat the warts because, it cured the above $10 \mathrm{~cm}$ diameter size warts and very much economical.

Farmers can treat warts on their animals by using this herbals available in and around their home. This result clearly proved that herbal remedies were effective (84\%) for the treatment of warts in animals.

The study demonstrated that herbal paste containing Euphorbia hirta, Allium sativum, Musa paradisiacal, Acalypha indica and Zingiber officinale was potentially better to treat warts in cattle and thus provide a cost effective option to treat warts, even when warts are bigger and diffused.

\section{Acknowledgement}

The authors sincerely thank a host of traditional-knowledge holders for their (herbal) knowledge and the inspiration they provided. We thank Dr.T.Umakanthan and Dr.C.Ananthan for their support. We also thank the animal-owners and the veterinary practitioners who helped in the study.

\section{References}

Agarwal KC (1991) Therapeutic action of garlic constituents. Med Res Rev: 16(1): pp111-124

Awang (1992). Ginger, Can.Pharm.J., 125, pp. 309-311

Bhasker joshi (2011). The magical herb
"Euphorbia hirta" An important traditional therapeutic herb for wart disease among the Vangujjars of forest near Kashipur, Uttarkhand, New York Science Journal; 4(2) pp 96-97.

Bloch N, Sutton R.H, and Sprad brow R.B. (1994) "Bovine cutaneous papillomas associated with bovine papilloma virus type 5 "Archives of virology, vol 138, no 3-4, pp 373-377.

Campo MS (1997). Review bovine papillomavirus and cancer. Vet.J, 154(3); pp 175-188.

Campo MS (2002) Animal models of papilloma virus pathogenesis. Virus Res; 89: pp 249-261.

Campo MS (2002) Bovine papillomavirus: old system, new lesions.In: Campo, M.S. (eds). Papillomavirus research from natural history to vaccine and beyond. Caister Academic Press, Wymond ham, Chap, 23: pp373-383.

Catrox M, Martin SA, Petrella S, Souza F, Nastari B (2013) Ultrastructural study of bovine papillomavirus during outbreaks in Brazil. Int.J.Morphol.31: pp 777-784.

De Villers, E.M., Fauquet, C., Broker, T.R., Bernard, H.U., and Zur Hausen, $\mathrm{H}$ (2004). Classification of papillomaviruses. Virology, 324: pp17-27.

Fayez Awadalla Salib and Haithm Ali Farghali (2011). Clinical, epidemiological and therapeutic studies on bovine Papillomatosis in Northern Oases, Egypt in 2008, Veterinary world, Vol 4(2): pp 53-59.

Inayat, A., Mubammed, G., Asi, M.N., Saqin, $M$ and Athar, M (1999). Use of autogenous vaccine for the treatment of generalized Papillomatosis in cattle. Pakist. Vet. J. 19: pp102-103.

Islam, M.T.de., $\quad$ Alencar. $\quad$ M.V.da., Conceisao. M.K. da., Conceisao. M.K.de. Carvalho. M.A.A.de., Sousa, 
D.P.de., Freitas, R.M, (2015) Phytolin a pharma-medico-stance, Chemico Biological Interactions, 240: pp. 6073.

Jarrett W.F.H., Campo M.S., O'neil B.W., Laird H.M., and Wcoggins L. A novel bovine papillomavirus (BPV6) causing true epithelial papillomas of the mammary gland skin (1984): A member of a proposed new BPV subgroup, Virology, Vol. 136, no.2: pp 255-264.

Jelinek.F and Tachezy R (2005) "Cutaneous Papillomatosis in cattle", Journal of comparative pathology, vol.132, no 1, pp 70-81.

Kumar D (2002). The use and relevance of ethno veterinary practices in sheep. Ind. J. Small Ruminants; 8(2): pp. 124128.

Kumar S., Malhotra R., Kumar D, (2010) Euphorbia hirta: Its chemistry, traditional and medicinal uses, and pharmacological activities. Pharmacognosy Review; 4:58-61.

Kavitha N.V., Vimal Rajkumar N and Jiji R.S (2014). Papillomatosis in jersey cows and its different medical treatment, International Journal of Science, Environment and Technology. vol. 3, no.2, pp. 692-694.

Leal A.M., Ferraz O.P., Carvaiho C., Freitas A.C., Beniston R.G., Becak W., Campo M.S and Stoccodos santos R.C (2003). Quercetin induces structural chromosome aberrations and uncommon rearrangements in bovine cells transformed by the E7 protein of bovine papilloma virus type-4; Vet.Compo.Pathol. 1: pp. 15-21.

Mc Corkle CM. (1986).An introduction to ethno veterinary research and development. J.Ethnobiol: 6; pp 129149.

McMurray HR., Nguyen D., West brook TF, Mc Acne DJ (2001); Biology of human papillomaviruses. Int. J. Exp. Pathol; 82: pp 15-23.

Mohammed A. Hamad, Ahmed Majeed AIShammari, Shoni M. Odisho, Nabi y. Yaseen (2017). Molecular epidemiology of bovine Papillomatosis and identification of three genotypes in Central Iraq, Inter Virology; 60: pp 156-164.

Nasir L., Campo MS (2006).Bovine papillomaviruses: their role in the etiology of cutaneous tumours of bovids and equids. Vet. Dermatol; 19(5): pp 243-254.

Ogawa T., Tomita Y., Okada M., Shinozaki K., Kubonoya H., Kaiho L., Shirasawa H (2004). Broad-spectrum detection of papillomaviruses in bovine teat papillomas and healthy teat skin.. J.Gen.Virol; 85: pp 2191-2197.

Otter and Leonard D (2003). Fibropapillomatosis outbreak in calves. Vet.Rec; 153(18): pp 570-571.

Ogawa T., Tomita Y., Okada M., and Shirasawa H, (2007). "Complete genome and phylogenetic position of bovine papillomavirus type 7". Journal of General Virology, vol 88, no 7: pp 1934-38.

Constable, P. D., Hinchcliff, K. W., Done, A. H. and Grunberg, W. 2017. Veterinary Medicine. A textbook of the diseases of cattle, horses, sheep, pigs and goats. 11th edn., W.B. Saunders Elsevier, Philadelphia. pp. 1580.

Somvanshi, R and Sharma, R.D. (1986). Therapeutic management of cutaneous warts in a heifer by Thuja. Indian. Vet. Med., 20: pp 234-235.

Silverberg, NB (2002). Garlic cloves for Verruca vulgaris, Peditar Dermatol: 19(2): pp183.

Silva, LAF., Verissimo, ACC., Filho PRLV., Fioravanti MCC., Eurides D., Linhares GCF., Romani AF., Trindade BR. (2004). Revista da FZVA, 11: pp 153- 
165.

Singh V., Somvanshi, R., Tiwari, AK (2009).

Papillomatosis in Indian cattle; occurrence and etiopathology. Indian. J. Vet. Pathol; 33: pp 52-57.

Sampath Kumar, K.P., Debjit Bhowmik, Duraivel, S., Umadevi, M. (2012). Traditional and medicinal uses of banana. Journal of Pharmacognosy and Phytochemistry. Vol. 1. no: 3.

Terziev G., Roydev R., Kalkanov I., Borisson IV., Dinev IV. (2015). Papillomatosis in heifers- comparative studies on surgical excision and autogenous vaccine therapies. Trakia Journal of Sciences, vol: 13, suppl. 2: pp 274279.

Zabra beygom mousavi, Abolfath mebrabian, Fereshtech golfakhrabadi, Foroogh Namjoyan (2018). A clinical study of efficacy of garlic extract versus cryotherapy in the treatment of male genital warts. Dermatologica Sinica, 36: pp 196-199.

\section{How to cite this article:}

Karthick Kumar, N., S. Sivaraman and Punniamurthy, N. 2020. Field Study on the Beneficial Effects of Fresh Herbals against Warts in Cattle: A Review of Clinical Cases. Int.J.Curr.Microbiol.App.Sci. 9(12): 1354-1363. doi: https://doi.org/10.20546/ijcmas.2020.912.165 